\title{
Evolutionary relationships of Red Jungle Fowl and chicken breeds
}

\author{
Irina G. Moiseyeva ${ }^{\mathrm{a}}$, Michael N. Romanov ${ }^{\mathrm{b} *}$, \\ Andrey A. Nikiforov ${ }^{\mathrm{a}}$, Antonina A. Sevastyanova ${ }^{\mathrm{c}}$, \\ Serafima K. SEMYenOva ${ }^{\mathrm{d}}$ \\ ${ }^{a}$ N.I. Vavilov Institute of General Genetics (RAS), Moscow 119991, Russia \\ b Department of Microbiology and Molecular Genetics, \\ 2209 Biomedical Physical Sciences, Michigan State University, \\ East Lansing, MI 48824-4320, USA \\ c All-Russian Poultry Research and Technological Institute (RAAS), Sergiev Posad, \\ Moscow Region 141300, Russia \\ ${ }^{\mathrm{d}}$ Institute of Gene Biology (RAS), Moscow 119334, Russia
}

(Received 2 January 2002; accepted 20 December 2002)

\begin{abstract}
Published results were reassessed and original data are provided regarding the origin and relatedness of four postulated chicken breed lineages, egg-type, game, meat-type and Bantam, to each other and to the basic ancestral species of jungle fowls, Gallus gallus. A system approach was employed concerning the planning of the experiments. One element of the system approach is the choice of the breeds to be compared with G. gallus. These breeds were supposed to represent major evolutionary branches of chickens. Four experiments on genetic relationships were conducted using different estimation criteria including morphological discrete characters, body measurements, biochemical markers, and the activity of serum esterase- 1 . The greatest similarity was found between G. gallus and the egg-type breeds of Mediterranean roots and/or true Bantams. This fact might testify that the indicated chicken groups occupied earlier stages in the evolution from the wild progenitor to the present biodiversity of chickens in the world.
\end{abstract}

Red Jungle Fowl / chicken breeds / evolution / genetic relationship / biodiversity

\section{INTRODUCTION}

Because of far inconsistent opinions regarding the origin of the domestic fowl, great interest has been stimulated in exploring the jungle fowl species including Gallus gallus (Red Jungle Fowl, shortly RJF), G. sonnerati (Grey Jungle Fowl), G. lafayettei (Ceylon Jungle Fowl) and G. varius (Green Jungle Fowl) that nowadays inhabit India, Indo-China, South China, the Philippines

\footnotetext{
* Correspondence and reprints

E-mail: romanoff@pilot.msu.edu
} 
and Indonesia. The widely spread species G. gallus has been most fully described for discrete morphological and metric quantitative traits $[9,15,16,32$, $35,40-42]$ and, over the last decades, for biochemical $[4,5,7,35]$ and molecular $[1,2,24,44,48]$ markers. Comparative research of four representatives of the Gallus genus and chicken breeds showed that G. gallus is the closest species to chickens for most traits studied in comparison with the other jungle fowls [1, $2,9,15,25,54,57]$.

One of the important unsolved questions is which chicken breed groups are the closest to G. gallus and, therefore, what types of domesticated fowls are the most ancient. There are, however, a number of difficulties in answering these questions, and it has been impossible so far to establish what evolutionary branches of chicken breeds are the closest to their major progenitor. These implications include:

(a) the possible contamination of the wild species with the domestic genes [11]; (b) the use of different markers; (c) an insufficient diagnostic value from the phylogenetic point of view that some markers probably have; (d) the selection of different breeds in the studies of different authors that are incomparable and do not meet experimental goals; (e) frequently, a lack of genetic purity of chicken breeds; (f) their development, as a rule, on the basis of several breed crosses; and (g) the application of different mathematical methods of data analysis.

In the present study, we state our opinions concerning the similarity and evolutionary relationships between G. gallus and different chicken breeds. This was done by exploiting the system approach in planning our own experiments and taking into account a total combination of the facts known to us, instead of the results of a single examination.

\section{MATERIALS AND METHODS}

Our investigations on comparative genetics of G. gallus and chickens have been carried out since 1982 . The results obtained have been partly published [29,32-37]. In the present study, sets of the compared breeds were reconsidered in terms of the objectives claimed in the introduction. Previously obtained data were reassessed using novel programs of mathematical analysis.

The phenotypic description, measure of body parts, and examination of biochemical polymorphisms were carried out on the G. gallus individuals kept in the Moscow Zoo, which were a mixture of several subspecies (the species consists of five subspecies including G. g. bankiva, G. g. gallus, G. g. jabouillei, G. g. murghi, and G. g. spadiceus), and on chicken breeds with various morphological types and different origins. Hereby, we employed both a random and goal-directed selection of the breeds that was a crucial element of the system approach in planning the experiments. It included a sampling 
of the breeds representing four evolutionary lineages of the domestic fowl hypothesized in our previous paper [31] and to be reassessed in the present study: (1) the egg-type, of Mediterranean roots (hereafter we will briefly designate it as the "egg-type"); (2) game, and (3) meat-type, of Asiatic roots; and (4) true Bantams of various descent.

We conducted four experiments using several trait categories: morphological discrete characters, body measurements, and biochemical markers. In Experiments Ia and $\mathrm{Ib}$, morphological traits including 24 characters and 48 character states/variants (Ia) or, alternatively, 31 characters and 72 states (Ib) were used. In Experiment Ia, the studied breed set was a random sample. In all other experiments, we did a special selection in accordance with the above mentioned major evolution directions in the course of chicken domestication. A list of the breeds (Experiments Ia and Ib) and the numbers of the individuals observed (Experiments II, III and IV) are shown in Table I.

A set of morphological characters was chosen on the basis of breed standards, our own observations and breed descriptions found in the literature. Information on the Chinese breeds was obtained according to our own scheme from a Chinese group led by Dr. Z. Yuguo, Dept. of Biology, China Agricultural University, Beijing, as well as from the monograph Poultry Breeds in China [3]. Information about a Vietnamese breed was kindly provided by Professor Liong, Vietnam National University of Hanoi. A list of the morphological characters used in Experiment Ia has been published elsewhere [35], those used in Experiment $\mathrm{Ib}$ being listed in Table II of the present study. In Experiment Ib, we used the same characters as in Experiment Ia but with some modifications regarding their set and number of variants so that those traits, which were characterized by color varieties, were excluded. New characters, which more fully determined the entire morphotypological make-up of a breed, were added. In our study, we considered this approach more correct because the phylogenetic relationships of the wild species with chickens should be sought by considering general breed characteristics and diverting attention from such details as color varieties. Moreover, as one can logically conclude, such an archetype of a breed is a more ancient formation in the evolution than breed varieties since the differentiation of a breed into smaller "taxonomic" units occurred undoubtedly later. The possibility to analyze a hypothetical archetype of a breed is of a great advantage in utilizing morphological traits. Other criteria do not give that opportunity.

In Experiment II, morphological metric traits including 10 body measurements (diagonal and direct back lengths, shank length and circumference, breast depth and circumference, pelvis width, keel length, and comb length and height) were obtained in females and males at the age of 12 months using standard zootechnical procedures [50]. These quantitative traits have a great coefficient of heritability $\left(h^{2} \approx 0.5\right)$ and a low within-population variability. 
Table I. List of breeds and numbers of specimens examined in Experiments I-IV.

(continued on the next page)

Chicken

breeds/varieties/populations

\section{Experiments}

\begin{tabular}{|c|c|c|c|c|c|c|c|c|}
\hline & \multirow{2}{*}{\multicolumn{2}{|c|}{$\begin{array}{l}\text { Ia Ib } \\
\begin{array}{l}\text { Morpholo- } \\
\text { gical }\end{array} \\
\text { characters }\end{array}$}} & \multicolumn{2}{|c|}{$\begin{array}{c}\text { II } \\
\text { Body } \\
\text { measure- } \\
\text { ments }\end{array}$} & \multicolumn{2}{|c|}{$\begin{array}{c}\text { III } \\
\text { Genetic } \\
\text { biochemical } \\
\text { markers }\end{array}$} & \multicolumn{2}{|c|}{$\begin{array}{c}\mathrm{IV} \\
\text { Biochemical } \\
\text { trait (serum } \\
\text { esterase-1 } \\
\text { activity) } \\
\end{array}$} \\
\hline & & & $N$ & $P$ & $N$ & $P$ & $\bar{N}$ & $P$ \\
\hline G. gallus & + & + & $10-2^{(1)}$ & 1 & $14-91^{(2)}$ & $4-8^{(3)}$ & 10 & 1 \\
\hline \multicolumn{9}{|l|}{ Breeds } \\
\hline Adler Silver & + & & & & & & & \\
\hline Ancona & & + & & & & & & \\
\hline Andalusian Blue & & + & & & $4-21$ & $2-3$ & 13 & 2 \\
\hline $\begin{array}{l}\text { Bantam (mixture of } \\
\text { Bantam-type varieties) }\end{array}$ & + & & $29-9$ & 1 & $21-87$ & $3-6$ & 19 & 1 \\
\hline \multicolumn{9}{|l|}{ Bohemian Golden Kropenka +} \\
\hline Brahma & & + & & & & & & \\
\hline Brahma Light & + & & $5-0$ & 1 & $2-32$ & $1-2$ & 9 & 1 \\
\hline California Grey & & & & & & & 50 & 1 \\
\hline Chabo & & + & & & 11-149 & $1-3$ & & \\
\hline Chinese Game & & + & & & & & & \\
\hline Cochin & & + & & & $3-6$ & 1 & 7 & 1 \\
\hline Cornish & & + & & & & & & \\
\hline Cornish White & + & & $31-16$ & 1 & & & 80 & 2 \\
\hline $\begin{array}{l}\text { Dong Tao (Vietnamese } \\
\text { Game) }\end{array}$ & & + & & & & & & \\
\hline Frizzle Red & + & & & & & & & \\
\hline $\begin{array}{l}\text { Gilanian } \\
\text { Gilanian Red }\end{array}$ & + & + & & & & & & \\
\hline $\begin{array}{l}\text { Hybrid Moscow, Line M5 × } \\
\text { Leghorn White }\end{array}$ & & & & & & & 66 & 1 \\
\hline Kuchino Jubilee & + & & & & & & & \\
\hline Kulangi & & + & $8-0$ & 1 & & & & \\
\hline Kulangi Red & + & & & & $9-36$ & $1-2$ & 36 & 2 \\
\hline Leghorn & & + & & & & & & \\
\hline Leghorn Brown & + & & $46-12$ & 1 & 119-149 & $3-4$ & 90 & 2 \\
\hline Leghorn White & + & & & & $1760-1912 \mathrm{~S}$ & $21-78$ & & \\
\hline $\begin{array}{l}\text { Hybrid } \mathrm{C} 1 \times \mathrm{C} 2 \text { of Hisex } \\
\text { White cross }\end{array}$ & & & & & & & 53 & 1 \\
\hline Line B21 & & & & & & & 131 & 1 \\
\hline Leningrad White & + & & & & & & & \\
\hline Malay & & + & $18-6$ & 1 & & & & \\
\hline Malay Red & + & & & & $21-27$ & $1-2$ & 23 & 1 \\
\hline Minorca & & + & & & & & & \\
\hline Minorca Black & + & & $20-7$ & 1 & $41-179$ & $2-4$ & 18 & 1 \\
\hline
\end{tabular}


Table I. Continued.

Chicken

breeds/varieties/populations
Experiments

\begin{tabular}{|c|c|c|c|}
\hline Ia & II & III & IV \\
\hline \multirow[t]{2}{*}{$\begin{array}{l}\text { Morpholo- } \\
\text { gical } \\
\text { characters }\end{array}$} & $\begin{array}{l}\text { Body } \\
\text { measure- } \\
\text { ments }\end{array}$ & $\begin{array}{c}\text { Genetic } \\
\text { biochemical } \\
\text { markers }\end{array}$ & $\begin{array}{c}\text { Biochemical } \\
\text { trait (serum } \\
\text { esterase-1 } \\
\text { activity) }\end{array}$ \\
\hline & $N$ & $N$ & $N$ \\
\hline
\end{tabular}

\begin{tabular}{|c|c|c|c|c|c|c|c|c|}
\hline Moscow & + & & & & & & & \\
\hline Moscow Game & & + & $3-2$ & 1 & $4-5$ & $1-2$ & 5 & 1 \\
\hline Naked Neck Red & + & & & & & & & \\
\hline New Hampshire & + & & & & & & & \\
\hline Old English Game & + & & & & & & & \\
\hline Orloff Red & + & & & & & & & \\
\hline Pervomai & + & & & & & & & \\
\hline Plymouth Rock Barred & + & & & & & & & \\
\hline Plymouth Rock White & & & & & $214-2530$ & $3-18$ & & \\
\hline
\end{tabular}

\begin{tabular}{lllllllll}
\hline Poltava Clay & + & & & & & & \\
\hline Rhode Island Red & + & & & & & & \\
\hline Russian Korolyok Bantam & & + & $0-6$ & 2 & & & \\
\hline Russian White & + & + & $20-6$ & 1 & $90-524$ & $4-5$ & 164 & 3 \\
\hline Sussex Light & + & & & & & & & \\
\hline Ukrainian Bearded (or & + & & & & & & &
\end{tabular}

Ushanka) Red

\begin{tabular}{ll}
\hline Ukrainian Crested Red & + \\
\hline Welsummer & + \\
\hline Yurlov Crower & +
\end{tabular}

(1) The first number means the number of hens, the second one the number of cocks measured in Experiment II; (2),(3) minimum and maximum numbers of specimens and populations examined for different biochemical markers in Experiment III. $N=$ number of individuals; $P=$ number of populations; " $+"=$ breeds studied in Experiments Ia and $\mathrm{Ib}$.

In Experiment III, electrophoreses in polyacrylamide and starch gels as described in [28] were applied to explore genetic biochemical markers including protein systems controlled by six loci and 16 alleles: $O V^{*} A, O V^{*} B ; G(3)^{*} A$, $G(3) * B, G(3) * J ; G(2) * A, G(2) * B ; T F^{*} A, T F^{*} B$, and $T F^{*} C$ in egg white; and $A L B^{*} A, A L B^{*} B, A L B^{*} C ; E S 1^{*} A, E S 1^{*} B$, and $E S 1^{*} C$ in blood serum. To increase sample representativity, allele frequencies were calculated as the averages of our own data and those published in the literature, if the latter are known.

In Experiment IV, the activity of serum esterase-1 (ESI) was visually estimated by the intensity of staining of esterase bands in the electrophoregrammes 
Table II. Genetic and phenotypic characteristics $(n=31)$ used for morphotypological differentiation of chicken breeds in Experiment Ib.

\begin{tabular}{|c|c|c|c|}
\hline Character & $\begin{array}{l}\text { Alleles controlling } \\
\text { character state }\end{array}$ & Character state & $\begin{array}{l}\text { No. of } \\
\text { character } \\
\text { states }\end{array}$ \\
\hline Comb shape controlled by the $R$ locus & $R * N \mid R * R$ & Single I rose & 2 \\
\hline Comb shape controlled by the $P$ locus & $P * N \mid P * P$ & Non-pea I pea & 2 \\
\hline Comb shape controlled by the $D$ locus & $D * N \mid D * D$ & Non-duplex I duplex & 2 \\
\hline Crest & $C R * N \mid C R * C R$ & Absence I presence & 2 \\
\hline Muffs and beards & $M B^{*} N \mid M B * M B$ & Absence I presence & 2 \\
\hline Feather growth in chicks & $K^{*} N \mid K^{*} K$ & Early | late & 2 \\
\hline Feather structure controlled by the $F$ locus & $F^{*} N \mid F^{*} F$ & Non-frizzled feathers I frizzled feathers & 2 \\
\hline Feather structure controlled by the $H$ locus & $H^{*} N \mid H^{*} H$ & Non-silky feathers I silky feathers & 2 \\
\hline Henny feathering in cocks & $H F^{*} N \mid H F^{*} H F$ & Absence I presence & 2 \\
\hline Neck feathers & $N A * N \mid N A * N A$ & Presence I absence (naked neck) & 2 \\
\hline Vulture hocks & $V^{*} N \mid V^{*} V$ & Absence I presence & 2 \\
\hline Number of toes & $P O * N \mid P O * P O$ & Four I five (polydactily) & 2 \\
\hline Number of spurs & $M * N \mid M * M$ & One I multiple & 2 \\
\hline Tail & $R P * N \mid R P * R P$ & Absence I presence & 2 \\
\hline Body size & $D W * N \mid D W * B$ & Normal I dwarf (true Bantam-like) & 2 \\
\hline Skin color controlled by the $F M$ locus & $F M * N \mid F M * F M$ & Unpigmented (white, yellow) I black & 2 \\
\hline Eggshell color & Polygenic trait & White (tinted) I intensively coloured & 2 \\
\hline Earlobe color & Polygenic trait & White I red & 2 \\
\hline Wattle size & Polygenic trait & Medium | large I small/absence & 3 \\
\hline Shank feathering & Polygenic trait & Non-feathered I slightly feathered I well feathered & 3 \\
\hline Body posture & Polygenic trait & Horizontal I semi-vertical I vertical & 3 \\
\hline Plumage thickness & Polygenic trait & Thick I loose & 2 \\
\hline Breast shape in cocks & Polygenic trait & Convex I slightly convex I flat & 3 \\
\hline Tail length in cocks & Polygenic trait & Long I medium I short & 3 \\
\hline Tail carriage in cocks & Polygenic trait & Tail at an angle to the back I horizontal I vertical & 3 \\
\hline Tail volume in cocks & Polygenic trait & Voluminous I non-voluminous & 2 \\
\hline Hackle in cocks & Polygenic trait & Absence I presence & 2 \\
\hline Wing length & Polygenic trait & Medium I long I short & 3 \\
\hline Male body weight & Polygenic trait & Low $(<M-\delta) \mid$ medium $(M \pm \delta) \mid$ high $(>M+\delta)$ & 3 \\
\hline Back length in cocks & Polygenic trait & Short $(<M-\delta) \mid$ medium $(M \pm \delta) \mid$ long $(>M+\delta)$ & 3 \\
\hline Shank length in cocks & Polygenic trait & Short $(<M-\delta) \mid$ medium $(M \pm \delta) \mid$ long $(>M+\delta)$ & 3 \\
\hline
\end{tabular}

$M=$ mean across all breeds in Experiment Ib; $\delta=$ standard deviation. 
using a scale from 0 (absence of a band, i.e., zero activity) to 4 (maximum band intensity). Visual estimates were subsequently tested with a densitometer. Blood samples were taken at about a 12-month age. The experimental details regarding ES1 activity are given elsewhere [33].

Genetic distances between populations for discrete morphological characters were calculated using a cladistic technique $[18,20]$ and the PAUP computer program [53] in Experiment Ia, while the MATRIX (E.M. Myasnikova, Institute for High Performance Computing and Data Bases, PO Box 71, St. Petersburg 194291, Russia, and I.A. Zakharov, N.I. Vavilov Institute of General Genetics, Moscow 119991, Russia, 1994, unpublished) and PHYLIP [21] computer programs were employed in Experiment $\mathrm{Ib}$. Mathematical principles of the MATRIX program are described elsewhere [37]. The similarities between $G$. gallus and chicken breeds for body measurements were calculated by means of Euclidean distances and the STATISTICA/w 5.0 computer program (StatSoft Ltd., Bedford, Beds MK40 3EU, UK) and, additionally, using the PHYLIP software package. We computed genetic distances on the basis of allele frequencies in the biochemical loci between chicken population pairs using Nei algorithms [38,39] and the VOSTORG [61] or, alternatively, PHYLIP computer programs. Cluster analyses of distance matrices were done with the following methods: Maximum Parsimony [20], UPGMA [17,52], Neighbor Joining [46], and Maximum Likelihood [19].

\section{RESULTS}

In Experiment Ia [35], the presence or absence of the discrete morphological characters was examined in G. gallus and 29 chicken populations using the cladistic procedure that was theoretically developed for revealing phylogenetic relationships between populations. On the dendrogram in Figure 1, there are three clades. We were interested in the third clade whose first subcluster included two breed groupings; in one of these, G. gallus consolidated with the following breeds: Minorca Black, Russian White, Leghorn White, Moscow, Bantam, and Leghorn Brown. All these breeds belonged to the egg type, except for the Moscow and Bantam. However, the Moscow breed is supposed to have Mediterranean genes since it was developed by crossing the New Hampshire, Yurlov Crower and Leghorn Brown. The Bantams used for the given study were a mixture of Bantam-type breeds. The original Bantam forms came from Southeast Asia, although there is a controversy in the literature concerning their phylogenetic status [10,13-15,51].

There were three clusters on the dendrogram (Fig. 2) obtained from the data of Experiment Ib: (1) all game breeds and Cornish (the latter was previously considered as a game breed, too); (2) all egg-type breeds (Andalusian Blue, Minorca, Leghorn, Ancona, Russian White), G. gallus and two Bantam breeds 


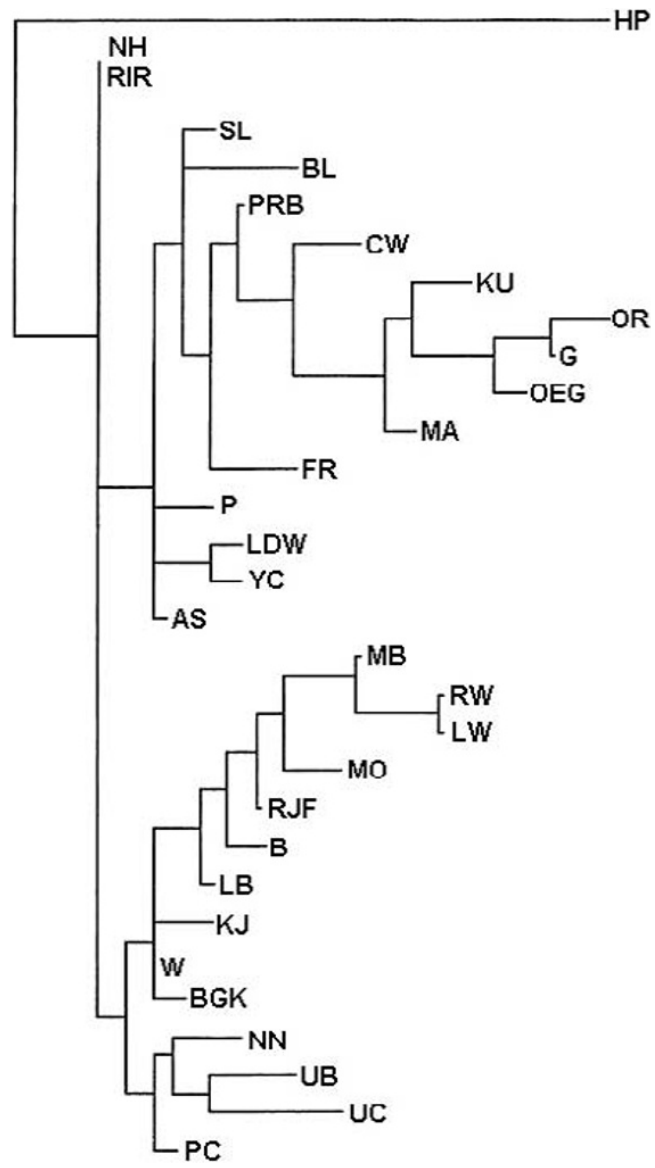

Figure 1. Kinship cladogram of G. gallus and 29 chicken breeds based on 24 discrete morphological characters (or 48 phenetic traits; see [35]) using the Maximum Parsimony method and the PAUP computer program. The matrix was obtained on the basis of the presence (code 1) or absence (code 2) of a trait in a breed. The outgroup, from which the dendrogram was computed, was an arbitrarily designed hypothetical population (HP), in which all traits were assumed to be zero [18]. The traits were not supposed to be ordered, that is, the evolutionary direction of the variation was not taken into account.

$\mathrm{AS}=$ Adler Silver; $\mathrm{B}=$ Bantam; BGK = Bohemian Golden Kropenka; BL = Brahma Light; $\mathrm{CW}=$ Cornish White; $\mathrm{FR}=$ Frizzle Red; $\mathrm{G}=$ Gilanian Red; KJ = Kuchino Jubilee; KU = Kulangi Red; LB = Leghorn Brown; LDW = Leningrad White; LW = Leghorn White; $\mathrm{MA}=$ Malay Red; $\mathrm{MB}=$ Minorca Black; $\mathrm{MO}=$ Moscow; $\mathrm{NH}=\mathrm{New}$ Hampshire; $\mathrm{NN}=$ Naked Neck Red; OEG = Old English Game; OR = Orloff Red; P $=$ Pervomai PC $=$ Poltava Clay; $\mathrm{PRB}=$ Plymouth Rock Barred; RIR $=$ Rhode Island Red; RJF = Red Jungle Fowl (G. gallus); RW = Russian White; SL = Sussex Light; $\mathrm{UB}=$ Ukrainian Bearded (or Ukrainian Ushanka) Red; UC = Ukrainian Crested Red; $\mathrm{W}=$ Welsummer; and $\mathrm{YC}=$ Yurlov Crower. 


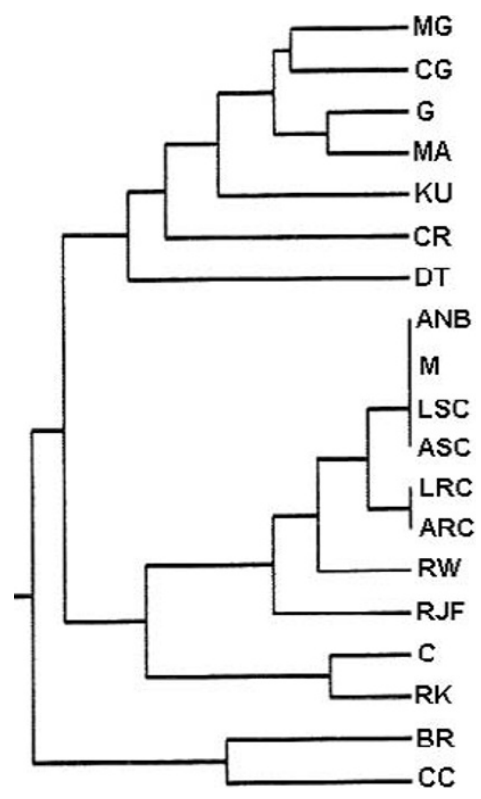

Figure 2. Dendrogram of morphotypological relationships among 19 chicken breeds based on 31 discrete morphological characters (or 72 phenetic traits listed in Tab. II): an UPGMA tree using the MATRIX and NEIGHBOR (PHYLIP software package) computer programs.

$\mathrm{ANB}=$ Andalusian Blue $; \mathrm{ARC}=$ Ancona Rose Comb ASC = Ancona Single Comb; $\mathrm{BR}=$ Brahma $\mathrm{C}=$ Chabo $\mathrm{CC}=$ Cochin $; \mathrm{CG}=$ Chinese Game; $\mathrm{CR}=$ Cornish; $\mathrm{DT}=$ Dong Tao (Vietnamese Game); $\mathrm{G}=$ Gilanian; $\mathrm{KU}=$ Kulangi; LRC = Leghorn Rose Comb; LSC = Leghorn Single Comb; MA = Malay; MG = Moscow Game; MI $=$ Minorca; RJF = Red Jungle Fowl; RK = Russian Korolyok Bantam; and RW = Russian White.

(Chabo, or Japanese Bantam, and Russian Korolyok, a Bantam of Russian origin); and (3) two Asiatic meat-type breeds (Brahma and Cochin). Since the Russian White breed was created by mating White Leghorns with indigenous Russian chickens, it has a remarkable Mediterranean genetic influence. The second cluster subdivides into two subclusters: the first of them consists of egg-type breeds and RJF and the second one includes Bantams.

In spite of some differences in the chosen breed sets, the characters used, and methods applied for determining the degree of breed similarity, the results of both Experiments (Ia and Ib) were principally in agreement: the wild progenitor of domestic fowl is grouped with the egg-type breeds and Bantams.

Experiment II was undertaken to compare the body size in females (Fig. 3A) and males (Fig. 3B) between G. gallus and nine (females) or eight (males) chicken breeds. It was found that on both UPGMA dendrograms based on Euclidean linkage distances, the populations formed three clusters: (1) egg- 
(A)

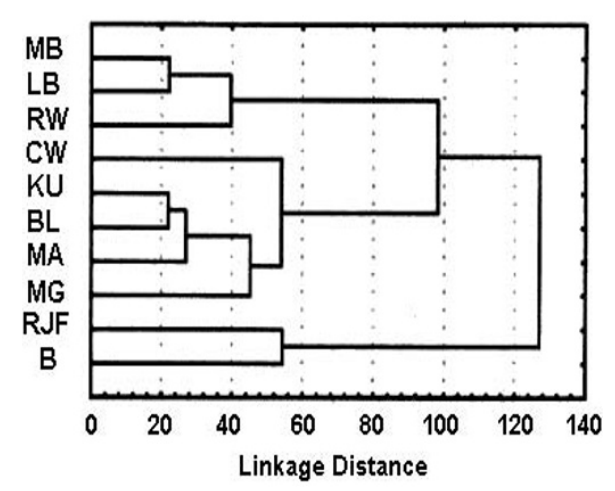

(B)

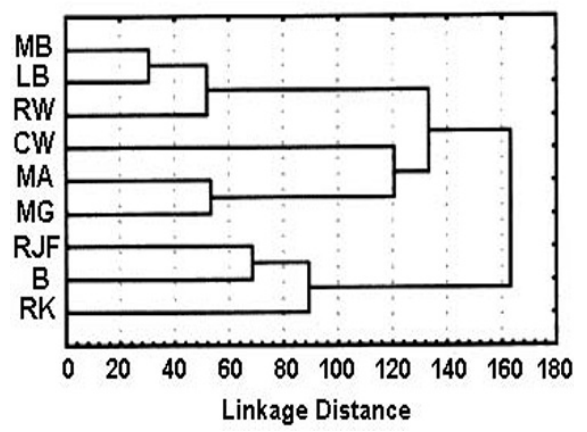

(C)

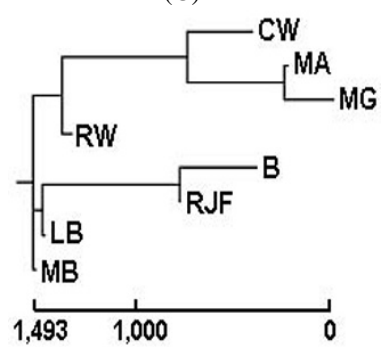

Figure 3. Dendrograms of chicken breed differentiation based on body measurements. (A) and (B): UPGMA tree diagrams for female (A) and male (B) body measurements using Euclidean linkage distances and the STATISTICA computer program; (C): a continuous character Maximum Likelihood tree for combined female and male body measurements using the CONTML computer program (PHYLIP software package); the units of length are amounts of expected accumulated variance (not time), the log likelihood (natural $\log$ ) of the tree is equal to -480.3 , and 15905 tree topologies have been tried.

$\mathrm{B}=$ Bantam; $\mathrm{BL}=$ Brahma Light; $\mathrm{CW}=$ Cornish White; $\mathrm{KU}=$ Kulangi; $\mathrm{LB}=$ Leghorn Brown; $\mathrm{MA}=$ Malay; $\mathrm{MB}=$ Minorca Black; $\mathrm{MG}=$ Moscow Game; RJF $=$ Red Jungle Fowl; RK = Russian Korolyok Bantam; and RW = Russian White.

type breeds with Mediterranean roots; (2) meat-type and game breeds with Asiatic roots; and (3) G. gallus and Bantams. When the Maximum Likelihood method was applied (Fig. 3C), the subcluster of G. gallus and Bantams merged with Brown Leghorns and Minorca Black. In a previous study [32], we stated that in the absence of Bantams in a sample of breeds, the wild species is clustered with egg-type chickens. However, G. gallus has never been grouped with meat-type or game breeds.

In Experiment III, a comparative analysis of biochemical marker frequencies was accomplished in G. gallus and 13 chicken breeds of different evolution 
(A)

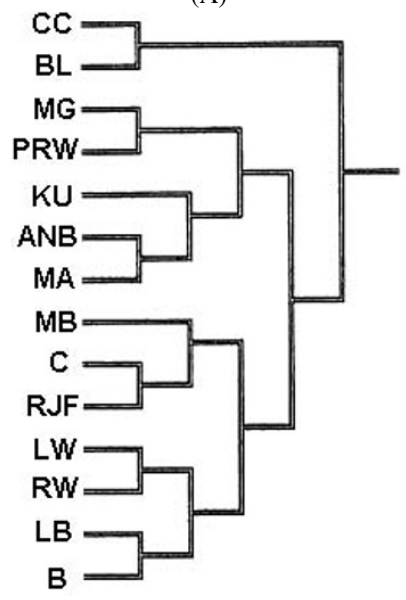

(B)

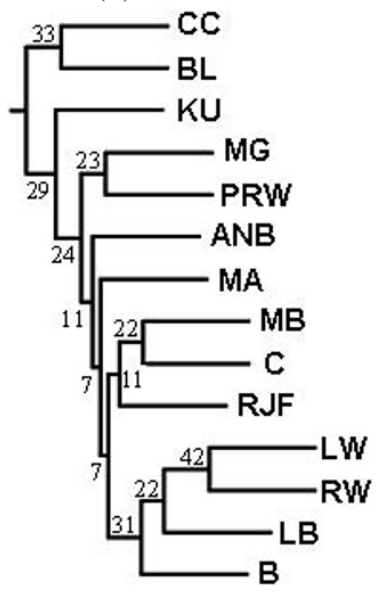

(C)

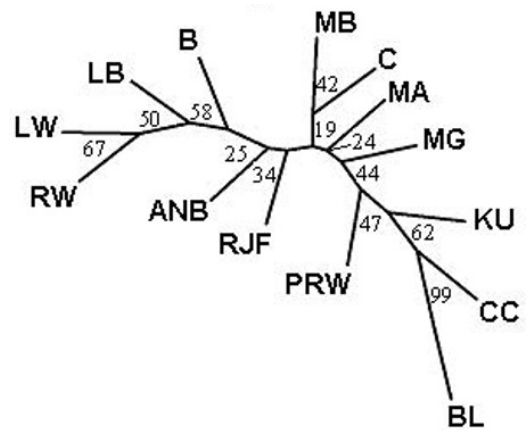

Figure 4. Dendrogram of genetic relationships among 14 chicken breeds based on allele frequencies in six egg white and blood protein loci ( $O V, G 3, G 2, T F, A L B, E S 1)$. (A) an UPGMA tree using the Nei [38] standard genetic distance and the VOSTORG computer program (without a bootstrapping procedure); (B) an UPGMA tree using the Nei [39] unbiased genetic distance and bootstrapping procedure (1000 replications with resampled loci) in the NEIGHBOR computer program; (C) a Neighbor-Joining tree using the Nei [39] unbiased genetic distance and bootstrapping procedure (1000 replications with resampled loci) in the NEIGHBOR computer program; (B) and (C) are the consensus trees, the numbers at the nodes being the percentage bootstrap values from 1000 replications with resampled loci.

$\mathrm{ANB}=$ Andalusian Blue; $\mathrm{B}=$ Bantam; $\mathrm{BL}=$ Brahma Light; $\mathrm{C}=$ Chabo $; \mathrm{CC}=$ Cochin; KU = Kulangi Red; LB = Leghorn Brown; LW = Leghorn White; MA = Malay Red; MB = Minorca Black; MG = Moscow Game; PRW = Plymouth Rock White; RJF = Red Jungle Fowl; and RW = Russian White.

lineages resulting from breed selection history. On a UPGMA dendrogram (Fig. 4A) constructed using Nei [38] standard genetic distance (without bootstrapping), three distinct clusters can be observed: (1) Cochin and Brahma 
Light; (2) Moscow Game, Plymouth Rock White, Kulangi, Malay and, as an exception, Andalusian Blue (of the egg type); and (3) G. gallus, egg-type breeds and Bantams. The third cluster was subdivided into two subclusters: (a) Minorca Black, Chabo and G. gallus; and (b) Leghorn Brown, Leghorn White, Russian White and Bantam.

A similar tree topology was obtained using the Nei [39] unbiased genetic distance, UPGMA and bootstrapping procedures (Fig. 4B), except the more exactly defined positions of a few breeds. Finally, in a Neighbor-Joining tree (Fig. 4C), all Asiatics were on the right side of the tree starting from the Malay and ending with the Brahma, and all Mediterranean-type breeds, Bantams and RJF were on the left side. Also, there was no mixing of Asiatics and Mediterranean-type breeds in this tree unlike the UPGMA trees. Noteworthy, the RJF was in a more independent position among Mediterranean-type breeds while in the UPGMA tree the RJF was in the subcluster with the Chabo and Minorca. Although the bootstrap support values were small, we can, nevertheless, rely upon the trees because the RJF entered the UPGMA cluster with all Bantams and Mediterranean-type breeds (except Andalusian Blue) or was again on the left side of the Neighbor-Joining tree along with all Mediterranean-type breeds and Bantams.

In our preliminary study [34], when comparing G. gallus only with two breed groups (egg-type and Asiatic meat-type/game breeds), the RJF was united with the first group, that is, with the egg-type breeds. If the breed set is different, the breed relationships could be different [35]. So, the set of compared breeds can largely affect the results of clustering.

The highest contribution to the distance matrix was established for the $G(3)$ and ESI loci out of the six biochemical marker loci used. The egg-type breeds and G. gallus were characterized by a greater frequency of the alleles $G(3) * A$ and $E S I * A$, and by a lower frequency of the $B$ alleles of the same loci. In the breed group of Asiatic origin, there was a reverse variation of the allele frequencies [35].

The results of the serum esterase-1 activity evaluation in G. gallus and various chicken breed groups (Experiment IV) are presented in Table III. The egg-type breed group and G. gallus had lower esterase-1 activity values ( 0.75 and 0.82 , respectively), while the Asiatic group of the meat-type and game breeds had significantly greater values (1.22 and 1.21, respectively) as compared to the egg-type group alone. The greatest esterase-1 activity was detected in the Bantam group (1.73), which was significantly distinguished from the other groups. A tendency of similarity between $G$. gallus and the egg-type breeds (as compared with other breed groups) was quite obvious. Unfortunately, we were only able to survey ten RJF individuals, which increased the standard error value to a greater extent and resulted in an insignificant difference. 
Table III. Average activity of serum esterase-1 in different chicken population groups.

\begin{tabular}{|c|c|c|c|}
\hline \multirow{3}{*}{$\begin{array}{l}\text { Population groups } \\
\text { 1. G. gallus }\end{array}$} & \multirow{2}{*}{\multicolumn{2}{|c|}{$\frac{\text { No. of }}{\text { populations individual }}$}} & \multirow[t]{2}{*}{$M \pm m$} \\
\hline & & & \\
\hline & 1 & 10 & $0.820 \pm 0.250^{\mathrm{a}, \mathrm{b}}$ \\
\hline $\begin{array}{l}\text { 2. Egg type of Mediterranean roots } \\
\text { (Andalusian Blue; California Grey; a hybrid } \\
\text { Moscow, Line M } 5 \times \text { Leghorn White; } \\
\text { Leghorn Brown; Leghorn White, Line B } 21 \\
\text { and a hybrid C } 1 \times \text { C } 2 \text { of Hisex White cross; } \\
\text { Minorca Black; Russian White) }\end{array}$ & 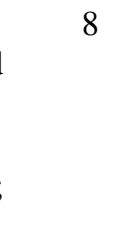 & 585 & $0.750 \pm 0.025^{\mathrm{a}}$ \\
\hline $\begin{array}{l}\text { 3. Meat type of Asiatic origin (Brahma } \\
\text { Light, Cochin, Cornish White) }\end{array}$ & 3 & 96 & $1.218 \pm 0.092^{b}$ \\
\hline $\begin{array}{l}\text { 4. Game type of Asiatic origin (Kulangi } \\
\text { Red, Malay Red, Moscow Game) }\end{array}$ & 3 & 64 & $1.209 \pm 0.103^{b}$ \\
\hline 5. Bantam & 1 & 19 & $1.730 \pm 0.212^{\mathrm{c}}$ \\
\hline
\end{tabular}

$M=$ mean value; $m=$ standard error. ${ }^{\mathrm{a}-\mathrm{c}}$ Means within a column and variable with no common superscripts differ significantly $(P<0.05)$ based on the Student $t$-test.

\section{DISCUSSION}

The comparison of our own data and literature data concerning the analogous categories of traits in G. gallus and chickens was quite complicated since in the different studies there were different samples of breeds, different sets and numbers of biochemical markers, different statistical software programs, etc. Nevertheless, we will try to summarize the research results regarding the degree of similarity between either the domestic type and the wild ancestor, that is, the origin succession of domestic breed types in the historical course of domestication.

Judging from the available information on the similarity of G. gallus with domestics, we can single out the following general principles. In the aggregate of morphological and biochemical markers ([34,35,37]; the present study, Experiments Ia, Ib, III and IV), G. gallus united with the egg-type breeds of Mediterranean roots and Bantams but was closer to the former. As to the voice characteristics [9], body measurements ([36,47]; the present study, Experiment II), and some blood groups and other biochemical markers [43], the wild progenitor was closer to the Bantams than to the other breed groups.

A certain confirmation of our findings can be seen in another osteometrical investigation [47] that involved 80 individual measurements of the pelvic limb bones in G. gallus and 12 chicken breeds. The data were subjected to a principal component analysis. The breeds were divided into four groups according to the first principal component (size factor): (1) breeds of small size (RJF and 
Sebright Bantam); (2) breeds of intermediate/small size (White Leghorn S, Fayoumi, Brown Leghorn and Shokoku); (3) breeds of intermediate/large size (Nagoya Y, Australorp, Nagoya K, White Leghorn B, Tokarajidori and Taiwanjidori); and (4) breeds of large size (Rhode Island Red). The breeds were classified into three groups according to the second principal component (shape factor): (1) breeds of the slender type (RJF); (2) breeds of the intermediate type (Australorp, Sebright Bantam, Nagoya Y, Nagoya K, Taiwanjidori, Tokarajidori, White Leghorn S, Shokoku, White Leghorn B); and (3) breeds of the broad type (Brown Leghorn, Fayoumi, Rhode Island Red). The author concluded that on the basis of the principal components, the RJF were clearly distinguished from the domestic fowls by the pelvic limb bone size. However, we suggest that this conclusion is fair only with regards to the bone shape; when using the bone size, G. gallus was closer to the Sebright Bantam.

Comparative aspects of the biochemical polymorphism in G. gallus and chickens have been described in a number of publications. An extremely rare variant of ovoglobulin $G(3) * J$ was found in G. gallus and such breeds as Yokohama, Chabo, Formosan and Indian local breeds but not in others [4-6,8, 26]. On an electrophoregramme in the area between the transferrin and sampleloading region in the gel, there were two macroglobulin bands in G. gallus whereas the domestic chickens only had one [27]. A comparison of the allele frequencies in 16 blood protein loci of wild species of $G$. gallus of different geographic origins (Philippines, Thailand, and Indonesia) with those of the local Indonesian chickens has been reported [22,23]. On a dendrogram, all populations of G. gallus and chickens formed a common cluster, within which different geographic populations of G. gallus occupied different branches. The Indonesian G. gallus specimens were close to the local Indonesian chickens and the Thailand G. gallus group was the most distant from the other chicken populations. In another study [43], G. gallus, 15 Japanese breeds (including three Bantam breeds) and an Indonesian local strain were examined for four blood groups and seven biochemical loci; the RJF was clustered along with three Japanese Bantam breeds, the Satsuma-dori, Nagoya, and local Indonesian population.

Enough convincing evidence has also established a similarity for biochemical and molecular markers between indigenous chicken breeds and G. gallus populations inhabiting the same geographical region $[22,23,58]$. In other cases, especially with the usage of molecular markers $[45,59,60]$, a clear and repeated picture has not yet been achieved.

Two publications quoted previously [1,2] deal with the relationship range between the RJF and domestic fowl on the basis of mtDNA polymorphism. The nucleotide sequence divergence revealed a closer relationship between the Thai RJF and the Indonesian indigenous domestic fowls than between the Thai RJF and the White Leghorns. 
The polymorphisms of minisatellites were studied in the eight fowl stocks: wild red jungle fowl (WJF), domestic jungle fowl (DJF), two commercial egg laying and two broiler stocks, and Athens-Canadian and Athens random-bred lines [49]. The level of WJF DNA fingerprint band sharing was low with all stocks except with DJF. Hereby, we again draw attention to the fact that the "domestic" G. gallus showed much more similarity with domestic chickens than the wild G. gallus, which does not seem to be an exclusive event.

The same markers were applied for the evaluation of the similarities of DNA polymorphism between breeds and the species of jungle fowls using the band sharing values. Genetic distances between the domestics of Japanese and Chinese origin and the jungle fowls were estimated as the mean number of nucleotide substitutions per nucleotide site [58]. The results indicate that the RJF is relatively close to the domestic fowl, but not to G. varius. The band sharing values between the domestic chickens, on the one hand, and the species G. gallus, G. sonnerati, G. lafayettei, and G. varius, on the other hand, were respectively $0.272,0.221,0.233$ and 0.089 . In a subsequent study using minisatellites, the same Japanese researchers [59] clearly demonstrated a substantial contribution of the geographical component to the similarity degree between G. gallus, local domestics and their hybrids bred in Fiji and Western Samoa. The specimens of an RJF population kept at the Kagoshima University were also used in the investigation. The populations of intra-island Fijian and Western Samoan fowls had greater band sharing values and lesser genetic distances, i.e. they were close to each other. In contrast, the inter-island band sharing values (Fiji versus the Western Samoa) were lower thus showing a considerable between island variation and leading to the formation of two clusters on a dendrogram. A group of the G. gallus individuals from the Kagoshima University was not clustered on the dendrogram with other fowl populations including the RJF from other geographical locations. This is more evidence that the genetic variation of "domestic" G. gallus is significantly different from that of native representatives of the species.

The polymorphism of 42 microsatellite loci was examined in 23 highly inbred fowl lines derived from the RJF, Leghorn, Fayoumi and Castellana Negra breeds [60]. Genetic distances based on the proportion of shared alleles between jungle fowls and other lines were larger (1.12-5.38) as compared with distances between the domestic fowl lines (0.66-1.13).

Three RJF populations were compared with 17 chicken populations of the Ukrainian, Russian, German and Australian origins by polymorphism of 14 microsatellite loci covering 11 linkage groups [44]. As a result, the RJF formed a separate branch on the genetic relationship tree.

It should be admitted that the system approach in planning the experiments allowed our data to be more consistent with historical information and biological sense, and to be more constant and less controversial when 
using different traits than the results of other investigators. In the aggregate of three studied trait categories, G. gallus was closer to the Mediterranean breeds of the egg type and Bantams (depending on trait category and breed choice). The similarity between G. gallus (originally from Asia) and Mediterranean chickens can be explained by an assumption that the origin centers of all four evolutionary domestic types were in Asia including that of the egg type [37]. According to H.L. Schippers (Stichting De Hoenderhorst, Goldschmedingplantsoen 15, 1185 EM Amstelveen, The Netherlands; http://home.wanadoo.nl/gjosinga/raseng/indexe.htm), one of the Mediterranean breeds, the Leghorn, has an ancient origin and may have been existing for about 3000 years. Also, there is an obvious similarity of the plumage pattern in Light Brown Leghorns and RJF. Another interesting fact is that the meat-type and game breeds have been grouped together for certain traits. This could be explained by their close genetic kinship since meat-type chickens are known to have been the latest evolutionary lineage and are derived from game breeds.

One more important issue is to look into the causes of the obvious discrepancies between the observed and expected results in groupings of certain breeds obtained by using different traits. For example, in Experiment III the Andalusian Blue, a Mediterranean breed, was united with game and meattype breeds of Asiatic origin, and in Experiment IV the Bantams showed the highest esterase activity which we had not expected since for a number of traits Bantams often had some features in common with the ancestral form that had a lower enzyme activity. But, it was probably not worth expecting completely synonymous results in similar fields of biological research, since there are too many factors that influence the final results, and to take all of them into account seems to be impossible. As for our concrete cases, the numbers of the Andalusian Blue individuals examined were small $(\mathrm{N}=4-21)$, and Bantams were a mixture of varieties, their number being small as well $(\mathrm{N}=19)$. This result, however, needs to be confirmed by other studies, in particular, it would be worthwhile in future research to check if the fact of high esterase-1 activity shown on that Bantam group conforms to data from other Bantam-type breeds.

Our study on evaluating genetic affinity in various chicken populations and analyzing the appropriate literature data has shown that to get similar results that can be sufficiently well interpreted from the standpoints of known facts about chicken breed history, one depends on the system experiment planning [30,55, 56]. Important elements of the system approach are, in our case, the formulation of a clear research goal (i.e., figuring out the phylogenetic relationship between ancestral form and chicken breeds), the set of the breeds according to the selected research goal (i.e., the breed groups that represent the known evolutionary lineages), the choice of criteria to characterize the phylogenetic differences and the appreciation of all facts known to us, considering the subject. The system 
approach in experiment planning allows with more economical time costs, to seek an optimal strategy of investigation.

The same reasoning is applicable to searching for criteria of similarity assessment. Discrete morphological traits and body measurements are characteristics of the bird's external appearance and size that undoubtedly correlate with breed genetic structure developed throughout the evolutionary process. Biochemical markers were randomly chosen in our previous studies, although we did subsequently make sure that at least two $(G(3)$ and $E S 1)$ out of the six loci examined differentiated the breeds with Mediterranean and Asiatic roots sufficiently well. Esterase-1 activity is known to take part in lipid metabolism; therefore, light egg-type breeds as well as G. gallus have, as a rule, a lower level of activity than heavy meat-type and game breeds; so this character turned out to be an additional marker in discriminating between the above population groups.

Based on our findings, we can postulate with a sufficient likelihood that the first domesticated forms of the chicken resembled small poultry that more often had morphological types of contemporary egg-type fowl with Mediterranean roots and/or true Bantams. This hypothesis is in agreement with ancient depictions of domestic chickens, which had the egg-layer morphological type [12].

In conclusion, we propose for discussion a concept of chicken breed evolution and succession of breed origins over time. Up to date, in our opinion, all variable chicken breeds represent four evolutionary lineages: (1) egg type, or Mediterranean; (2) game; (3) meat type; and (4) Bantam. They did not arise simultaneously. Probably, the first forms were of the Mediterranean egg-layer and/or Bantam types. The game type of chicken breeds might also derive directly from the wild progenitor or, rather, from the egg-type birds. The latest evolutionary lineage was the meat type that is suggested to have descended from game breeds. If we take these circumstances into account (i.e., four major chicken breed forms and their origin succession over time), we believe that the results of the genetic studies done by different researchers would be comparable and consistent. The evolution of chicken breeds as well as those of other domestic animals is far from being completed. Probably, new breed forms will be discovered and entirely new types will be developed. This will happen inevitably in the course of incessant creative (and destructive) human activities with respect to those species we have tamed.

\section{ACKNOWLEDGEMENTS}

The work was supported by the Fundamental Research Program of the Russian Academy of Sciences Presidium "Developing the Genetic Foundation of the Biodiversity Conservation". We are grateful to Elio Corti and two anonymous reviewers for valuable suggestions. 


\section{REFERENCES}

[1] Akishinonomiya F., Miyake T., Sumi S., Takada M., Ohno S., Kondo N., One subspecies of the Red Jungle Fowl (Gallus gallus gallus) suffices as the matriarchic ancestor of all domestic breeds, Proc. Natl. Acad. Sci. USA 91 (1994) 12505-12509.

[2] Akishinonomiya F., Miyake T., Takada M., Shingu R., Endo T., Gojobori T., Kondo N., Ohno S., Monophyletic origin and unique dispersal patterns of domestic fowls, Proc. Natl. Acad. Sci. USA 93 (1996) 6792-6795.

[3] Anonymous, Poultry breeds in China, Shanghai Scientific \& Technical Publishers, Shanghai, 1989.

[4] Baker C.M.A., Molecular genetics of avian proteins. III. The egg proteins of an isolated population of Jungle Fowl, Gallus gallus L., Comp. Biochem. Physiol. 12 (1964) 389-403.

[5] Baker C.M.A., Molecular genetics of avian proteins. IX. Interspecific and intraspecific variation of egg white proteins of genus Gallus, Genetics 58 (1968) 211-226.

[6] Baker C.M.A., Manwell C., Molecular genetics of avian proteins. I. The eggwhite proteins of the domestic fowl, Br. Poult. Sci. 3 (1962) 161-174.

[7] Baker C.M.A., Manwell C., Molecular genetics of avian proteins. XI. Egg proteins of Gallus gallus, G. sonnerati and hybrids, Anim. Blood Groups Biochem. Genet. 3 (1972) 101-107.

[8] Baker C.M.A., Manwell C., Jayaprakash N., Francis N., Molecular genetics of avian proteins. X. Egg white protein polymorphism of indigenous Indian chickens, Comp. Biochem. Physiol., B. Comp. Biochem. 40 (1971) 147-153.

[9] Beebe W., A monograph of pheasants, Vols. I-IV, H.F. and G. Witherby, London, 1918-1922.

[10] Brisbin I.L., Concerns for the genetic integrity and conservation status of the Red Jungle Fowl, Tragopan 4 (1996) 11-12.

[11] Brown E., Poultry breeding and production, Vols. I \& II, Ernst Benn Ltd., London, 1929.

[12] Carter H., Mace A.C., The tomb of Tut-ankh-amen, Vols. I-III, Cassell, London, 1923.

[13] Crawford R.D., Origin and history of poultry species. Poultry genetic resources: evolution, diversity, and conservation, in: Crawford R.D. (Ed.), Poultry Breeding and Genetics, Elsevier, Amsterdam, 1990, pp. 1-59.

[14] Crawfurd J., A descriptive dictionary of the Indian islands and adjacent countries, Oxford University Press, Kuala Lumpur, New York, 1971.

[15] Darwin C., The variation of animals and plants under domestication, John Murray, London, 1868, pp. 273-335.

[16] Delacour J., The pheasants of the world, 2nd edn., Spur Publications, Hindhead, Surrey, 1977, pp. 119-136.

[17] Duran B.S., Odell P.L., Cluster analysis, Springer-Verlag, New York, 1974.

[18] Farris J.S., Outgroup and parsimony, Syst. Zool. 31 (1982) 328-334.

[19] Felsenstein J., Evolutionary trees from gene frequencies and quantitative characters: finding maximum likelihood estimates, Evolution 35 (1981) 1229-1242. 
[20] Felsenstein J., Parsimony in systematics: biological and statistical issues, Ann. Rev. Ecolog. Syst. 14 (1983) 313-333.

[21] Felsenstein J., PHYLIP: phylogenetic inference package, executables for 386 PCDOS, version 3.5c, University of Washington, Seattle, 1994.

[22] Hashiguchi T., Nishida T., Hayashi Y., Mansjoer S.S., Blood protein variations of the native and the jungle fowls in Indonesia, in: The Origin and Phylogeny of Indonesian Native Livestock, Report by Grant-in-Aid for Overseas Scientific Survey, No. 57043041, 1982, Research Group of Overseas Scientific Survey, Japan, pp. 97-109.

[23] Hashiguchi T., Nishida T., Hayashi Y., Maeda Y., Mansjoer S.S., Blood protein polymorphisms of native and jungle fowls in Indonesia, Asian-Australas J. Anim. Sci. 6 (1993) 27-35.

[24] Hillel J., Korol A., Kirzner V., Freidlin P., Weigend S., Barre-Dirie A., Groenen M.A.M., Crooijmans R.P.M.A., Tixier-Boichard M., Vignal A., Wimmers K., Burke T., Thomson P.A., Mäki-Tanila A., Elo K., Zhivotovsky L.A., Feldman M.W., Biodiversity of chickens based on DNA pools: first results of the EC funded project AVIANDIV, in: Preisinger R. (Ed.), Proceedings of the Poultry Genetics Symposium, 6-8 October 1999, Mariensee, Lohmann Tierzucht GmbH, Cuxhaven, pp. 22-29.

[25] Ivanov M.F., Poultry breeds, Ekonomicheskaya zhizn', Moscow, 1924.

[26] Kimura M., Electrophoresis of egg white proteins of the Japanese and the Formosan native fowls, Jap. Poultry Sci. 9 (1972) 237-238.

[27] Kimura M., Electrophoretic patterns of ovomacroglobulins of egg white from Red Jungle Fowl and the domestic fowl, Jap. Poultry Sci. 9 (1972) 185-186.

[28] Kutnyuk P.I., Volokhovich V.A., Moiseyeva I.G., Electrophoretic analysis of poultry proteins: technical recommendations, Kharkiv, 1986.

[29] Moiseyeva I.G., Ancient evidence for the origin and distribution of domestic fowl, in: Proceedings of the 10th European Conference "The Poultry Industry Towards the 21st Century", 21-28 June 1998, Jerusalem, Vol. I, pp. 244-245.

[30] Moiseyeva I.G., Principles of chicken breed classification, Sel'skokhozyaystvennaya biologiya 6 (1999) 23-32.

[31] Moiseyeva I.G., New approach to the construction of chicken breed classifications, Ptakhivnytstvo 51 (2001) 101-109.

[32] Moiseyeva I.G., Volokhovich V.A., Variation of qualitative traits of chicken exterior, in: Selection and Technological Processes in Poultry Industry, Stiintsa, Chisinau, 1987, pp. 70-74.

[33] Moiseyeva I.G., Semyenova S.K., Gorbachyova N.S., Volokhovich V.A., Semyenov B.A., Karimov K.K., The serum esterase-1 activity in domestic fowl of different practical use, Uspekhi sovremennoy genetiki 16 (1989) 189-206.

[34] Moiseyeva I.G., Bannikova L.V., Altukhov Yu.P., State of poultry breeding in Russia: genetic monitoring, Mezhdunarodnyi sel'skokhozyaystvennyi zhurnal 5-6 (1993) 66-69.

[35] Moiseyeva I.G., Semyenova S.K., Bannikova L.V., Filippova N.D., Genetic structure and origin of an old Russian Orloff chicken breed, Genetika 30 (1994) 681-694. 
[36] Moiseyeva I.G., Semyenova S.K., Gorbachyova N.S., Chicken breed differentiation estimated by body measurements, in: Pigarev N. (Ed.), Papers Presented at the Scientific Poultry Conference, Sergiev Posad, 1995, pp. 45-46.

[37] Moiseyeva I.G., Yuguo Z., Nikiforov A.A., Zakharov I.A., Comparative analysis of morphological traits in Mediterranean and Chinese breeds: the problem of the origin of the domestic chicken, Genetika 32 (1996) 1553-1561.

[38] Nei M., Genetic distances between populations, Am. Nat. 106 (1972) 283-292.

[39] Nei M., Estimation of average heterozygosity and genetic distance from a small number of individuals, Genetics 89 (1978) 583-590.

[40] Nishida T., Hayashi Y., Hashiguchi T., Mansjoer S.S., Ecological and morphological studies on the jungle fowl in Indonesia, Rep. Soc. Res. Native Livestock 10 (1983) 155-170.

[41] Nishida T., Hayashi Y., Fujioka T., Tsugiyama I., Mochizuki K., Osteometrical studies on the phylogenetic-relationships of Japanese native fowls, Jap. J. Vet. Sci. 47 (1985) 25-37.

[42] Nishida T., Hayashi Y., Hashiguchi T., Somatometrical studies on the morphological relationships of Japanese native fowls, Jap. J. Zootech. Sci. 56 (1985) 645-657.

[43] Okada I., Yamamoto Y., Hashiguchi T., Ito S., Phylogenetic studies on the Japanese native breeds of chickens, Jap. Poultry Sci. 21 (1984) 318-329.

[44] Romanov M.N., Weigend S., Analysis of genetic relationships between various populations of domestic and jungle fowl using microsatellite markers, Poultry Sci. 80 (2001) 1057-1063.

[45] Rosenberg N.A., Burke T., Elo K., Feldman M.W., Freidlin P.J., Groenen M.A.M., Hillel J., Mäki-Tanila A., Tixier-Boichard M., Vignal A., Wimmers K., Weigend S., Empirical evaluation of genetic clustering methods using multilocus genotypes from 20 chicken breeds, Genetics 159 (2001) 699-713.

[46] Saitou N., Nei M., The neighbor-joining method: a new method for reconstructing phylogenetic trees, Mol. Biol. Evol. 4 (1987) 406-425.

[47] Samejima M., Principal component analysis of measurements on the skeleton of Red Jungle Fowls and 12 breeds of domestic fowls. III. Ossa membri pelvini, Jap. Poultry Sci. 27 (1990) 141-161.

[48] Schmid M., Nanda I., Guttenbach M., Steinlein C., Hoehn M., Schartl M., Haaf T., Weigend S., Fries R., Buerstedde J.M., Wimmers K., Burt D.W., Smith J., A'Hara S., Law A., Griffin D.K., Bumstead N., Kaufman J., Thomson P.A., Burke T., Groenen M.A.M., Crooijmans R.P.M.A., Vignal A., Fillon V., Morisson M., Pitel F., Tixier-Boichard M., Ladjali-Mohammedi K., Hillel J., Mäki-Tanila A., Cheng H.H., Delany M.E., Burnside J., Mizuno S., First report on chicken genes and chromosomes 2000, Cytogenet. Cell Genet. 90 (2000) 169-218.

[49] Siegel P.B., Haberfeld A., Mukherjee T.K., Stallard L.C., Marks H.L., Anthony N.B., Dunnington E.A., Jungle fowl-domestic fowl relationships: a use of DNA fingerprinting, World's Poultry Sci. J. 48 (1992) 147-155.

[50] Smetnev S.I., Poultry breeding, Kolos, Moscow, 1978.

[51] Smith P., Daniel C., The chicken book, Little, Brown and Co., Toronto, 1975.

[52] Sneath P.H.A., Sokal R.R., Numerical taxonomy, Freeman, San Francisco, 1973.

[53] Swofford D.L., PAUP*: phylogenetic analysis using parsimony (* and other $^{*}$ methods), 4.0 edn., Sinauer, Sunderland, 1999. 
[54] Tegetmeier W.B., The poultry book: comprising the breeding and management of profitable and ornamental poultry, G. Routledge, London, New York, 1873.

[55] Urmantsev Yu.A., What can give to the biologist a consideration of the object as a system in the system of objects of the same kind?, Zhurnal obschey biologii 39 (1978) 699-718.

[56] Urmantsev Yu.A., Nine plus one etudes on system philosophy, Sovremennye tetradi, Moscow, 2001.

[57] West B., Zhou B.-X., Did chicken go North? New evidence for domestication, World's Poultry Sci. J. 45 (1989) 205-218.

[58] Yamashita H., Okamoto S., Maeda Y., Hashiguchi T., Genetic relationships among domestic and jungle fowls revealed by DNA fingerprinting analysis, Jap. Poultry Sci. 31 (1994) 335-344.

[59] Yamashita H., Nishida T., Tsunekawa N., Manuel P., Okamoto S., Maeda Y., Hashiguchi T., DNA fingerprinting analysis of native and red jungle fowls in Fiji and Western Samoa, Jap. Poultry Sci. 34 (1997) 9-20.

[60] Zhou H., Lamont S.J., Genetic characterization of biodiversity in highly inbred chicken lines by microsatellite markers, Anim. Genet. 30 (1999) 256-264.

[61] Zharkikh A.A., Rzhetsky A.Yu., Morosov P.S., Sitnikova T.L., Krushkal J.S., VOSTORG: a package of microcomputer programs for sequence analysis and construction of phylogenetic trees, Gene 101 (1991) 251-254.

To access this journal online: www.edpsciences.org 